\title{
PEMIKIRAN EKONOMI BISNIS
}

TUGAS CITATION

“THE CONDITION OF SUSTAINABILITY OF LOBSTERS IN INDONESIA AS

THE IMPACT OF REGULATION OF THE MINISTER OF MARINE AND FISHERY NUMBER 12 OF 2020 CONCERNING”

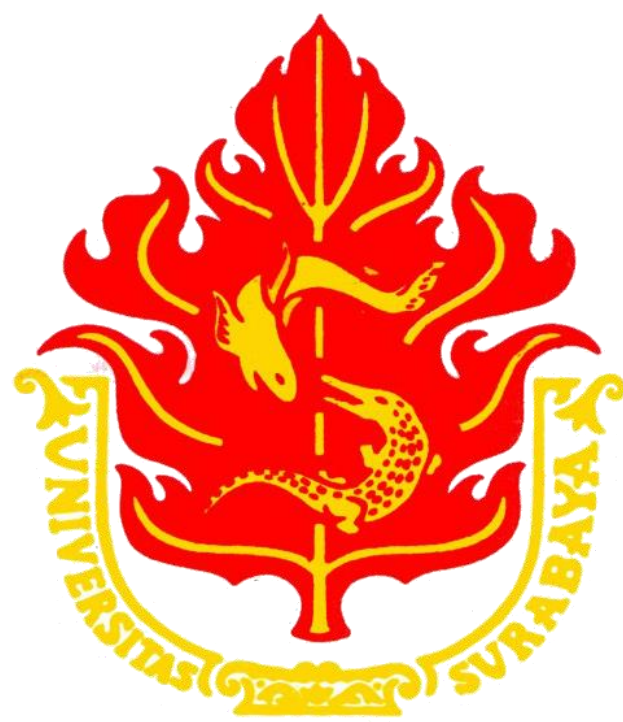

Oleh:

Felicya Christina Wijaya

130218022

KP B

FAKULTAS BISNIS DAN EKONOMIKA

UNIVERSITAS SURABAYA

2021 


\section{THE CONDITION OF SUSTAINABILITY OF LOBSTERS IN INDONESIA AS THE IMPACT OF REGULATION OF THE MINISTER OF MARINE AND FISHERY NUMBER 12 OF 2020 CONCERNING}

According to A.Z. Tayibnapis and L.E. Wuryaningsih, the new policy made by the Minister of Marine Affairs and Fisheries Number 12 of 2020 can provide flexibility in catching lobster seeds is tantamount to opening up massive exploitation and welcoming the extinction of lobster seeds in Indonesia. However, evaluation is still needed considering that business actors in Indonesia are not yet ready with the supporting facilities and infrastructure to carry out lobster seed cultivation.

As is well known, Indonesia is an archipelagic country with abundant marine resources which is a place of livelihood for fishermen using modern fishing gear to obtain these marine products. The Ministry of Marine Affairs and Fisheries revised 18 regulations in the fisheries sector and prepared 89 specific environmentally friendly fishing gears, because previously felt that it had caused unrest by legalizing fishing gear that was prohibited from being used, such as paying, shrimp trawl, and so on. One of the revised regulations is the Regulation of the Minister of Marine Affairs and Fisheries Number 12 of 2020 regarding the management of lobsters and crabs in the territory of the Republic of Indonesia. The government is currently preparing a 2020-2024 lobster cultivation roadmap, where in 2020, the value of lobster cultivation production will increase to IDR 1.73 trillion in 2024.

The use of lobsters for export must be managed by the state and the government must also be transparent so as not to create confusing opinions. This is because according to the Ombudsman of the Republic of Indonesia related policies that allow the export of lobster seeds are not in accordance with the mandate of the economic constitution which has been regulated in Article 33 of the 1945 Constitution paragraph 3 and paragraph 4 with the argument that lobster seeds are an extractive natural resource. The government continues to insist on implementing the Minister of Marine Affairs and Fisheries Regulation No 12 of 2020 with the argument of helping 13,000 small fishermen who have lost their livelihoods. The development of demand and supply in both global and international markets determines the price movements of lobsters and lobster seeds, as 
well as encourages the issuance of new policies related to cultivators. Marine resources owned by the community always have a tendency to be overexploited by using modern or cantrang equipment.

The report from the Roma Group in "The Limits to Growth" (Meadow, 1972) proves that the world tends to fail due to limited natural resources, but on the other hand the level of world consumption is increasing. An example is the lobster resources in 11 fisheries management areas in Indonesia which are in the red zone and the yellow zone, which indicates that the harvest of adult lobsters should not be increased but the catching of lobster seeds must be carried out with extreme care. There are 2 types of natural resources, namely natural resources that are newest and non-renewable. Renewable natural resources can naturally be created again at the speed of human exploitation, while non-renewable natural resources are natural resources that cannot be recreated.

Economically, the lobster seed export policy in Indonesia seems less profitable, but on the other hand, the legalization of lobster seed export has the potential to trigger massive exploitation of lobster seeds and will have a negative impact on the balance of the ecosystem. However, the Government considers that the export of lobster seeds is carried out for the benefit of fishermen who live from catching lobster seeds and for producing lobster cultivation. In 2024, the production value of cultivated lobster is projected to be IDR 1.73 trillion through the development of the upstream-downstream supply chain system. Some of the factors that cause Indonesian lobster exports to be unable to compete in the international market are logistical problems, lack of market control, and continuity in obtaining lobster seeds for cultivation. However, Indonesia has implemented certification of fish catches, traceability of fishery products, implementation of logbooks, and safeguarding marine resources through conservation of natural resources by reducing the risk of death of marine mammals in fishing activities.

Regulation of the Minister of Marine Affairs and Fisheries Number 12 of 2020 has a negative impact on the sustainability of lobsters in Indonesia and may not be enforced in 2020 and should be implemented in mid-2021, because this policy is related to Government Regulation Number 75 of 2015 concerning Types and Rates of Non-Tax State Revenue which is no longer relevant to the present or the future. The enactment of the Minister of Marine Affairs and Fisheries Regulation Number 12 of 2020 has a 
negative impact on the sustainability of lobsters in Indonesia, because this regulation favors investors more than fishermen or lobster cultivators and creates a scarcity of lobster seeds. Since the issuance of this regulation, the fate of lobster cultivators has deteriorated because the price of lobsters has dropped sharply making it difficult to sell them, while the fishermen have also been unable to continue the lobster enlargement business because lobster seeds have become increasingly expensive. Seeing this problem, steps that can be taken by the central government are to postpone the implementation of new policies, simplify central and regional licensing, stop the export of lobster seeds, reduce the risk of death of marine mammals, choose environmentally friendly lobster fishing gear, and restructure the partnership pattern so that there is certainty law for cultivators and fishermen. 